\title{
Educational Reform Via School Councils: Comparing Saskatchewan's School Community Councils to an International Precedent
}

\author{
Jane P. Preston (University of Saskatchewan)
}

\begin{abstract}
A variety of school governance reform movements directly affected community participation within schools globally during the 1980s and 1990s. This article highlights some of the economic, social, and political undercurrents at the core of this trend. Utilizing historical information as a comparative and dialectic backdrop, the societal and political intricacies interwoven into the recent inception of School Community Councils in Saskatchewan, Canada are explicated. Throughout this article, an overview of the purpose and responsibilities of Saskatchewan's School Community Councils are compared to and contrasted with the governing persuasion and power of a number of international school councils.

Résumé

Une série de mouvements de réforme de la gouvernance scolaire a directement touché la participation globale des communautés dans les écoles pendant les années 1980 et 1990. Cet article met en évidence certains facteurs économiques, sociaux, et politiques sous-jacents au cœur de cette tendance. Utilisant les informations historiques comme toile de fond comparative et dialectique, les complexités sociales et politiques entrelacées dans la récente création des conseils de la communauté scolaire en Saskatchewan, au Canada, sont développées. Tout au long de l'article, une vue d'ensemble des buts et responsabilités des conseils de la communauté scolaire en Saskatchewan est comparée et mise en contraste avec la persuasion et le pouvoir régissant d'un certain nombre de conseils scolaires internationaux.
\end{abstract}

Analyzing educational reform movements within international jurisdictions is irrefutably relevant when examining the school reform efforts that have taken place within Saskatchewan (Canada) within the last two years. A global perspective reveals that a diverse assortment of economic, social, and political motives undergird the inception of school councils; in turn, the impetus for incorporating School Community Councils within Saskatchewan can be situated with and compared to international causations. In this article, school councils within England, Wales, and the United States are specifically detailed because these areas share similar demographic and contextual components with Saskatchewan. For instance, 
these countries are predominantly English-speaking, industrialized nations, with traditional rural roots. The United States, so close in geographic proximity to Canada and Saskatchewan, is of particular interest to Canadians because the United States influences many Canadian trends within educational domains and beyond. Research from the 1980s and 1990s is specifically chosen, because it was during this epoch that, worldwide, the restructuring of school governance was the focal point of many new policies. Furthermore, at the start of the 1980s, arguments for parent involvement gained intensity and momentum, and, it was in part for this reason, school councils obtained international popularity during the 1980s.

In 2006, the Saskatchewan Government legislated the creation of School Community Councils. Analyzing why various forms of international school councils were created triggers an opportunity to reflect upon and discuss the contextual intricacies upon which School Community Councils were created. The purpose of this article is therefore twofold. First, I compare and contrast the historical precedents set by various international school councils with the onset and development of School Community Councils in Saskatchewan. Second, I analyze societal issues that endorsed school reforms both internationally and within Saskatchewan. Throughout the article, the purpose and responsibilities of the various forms of school councils are explicated.

\section{INTERNATIONAL SCHOOL REFORM MOVEMENTS OF THE 1980s AND 1990s}

Historically, economic and political reforms tend to go hand-in-hand with educational restructuring. Legitimacy of this statement can be found from Europe to North America; England, Wales and the United States are quality examples of how politics and education are often integrally connected. Moreover, school councils are an emergent component within the discussion of politics and education.

\section{Education Reform in England and Wales}

In many ways, the educational reform movements of England and Wales during the 1980s and 1900s were very centralized in nature. For example, The Education Reform Act of 1988 established a National Curriculum and National Assessment Tests (Fujita, 1999; Thomas, 1993). Shortly after these policies were implemented, public schools were forced to publish examination results, privileging parents to statistical results of student/school competence (Fujita, 1999; Thomas, 1993). The Education Act of 1992 established the Office for Standards in Education (Giles, 2006). This government organization was given the right to inspect educational activities and professional documents within any school of its choice. In addition, the quality of instructional deliverance, standards of student achievement, and management of school finances could be officially examined through the Office for Standards in Education.

According to Bolton (1993), The Education Acts of the 1980s and 1990s reflected a “...Thatcher Government's macro-philosophy that efficiency and 
quality are best sustained and enhanced in situations where users and customers have choice and the information and the scope to use it as they decide - in other words, where there is a market" (p. 5). Under the Education Act of 1980, open enrollment and per capita funding systems were introduced (Fujita, 1999). This Act empowered parents to select schools reflective of their corresponding values and home practices. Allegedly by liberating parental choice and forcing schools to compete for students, schools were pressurized to improve their programs and deliver a higher quality of education to students. In short, schools during this time were seen as small businesses. In order to attract desirable clientele, schools needed to compete with other schools vis-à-vis the types of specialized resources and programs they offered. Thomas (1993) believed a market-place philosophy enhances the power of the client (parents/students) and decreases the power of the producer (educators/schools).

Although England and Wales predominantly focused efforts on centralizing their education, conversely, other English and Welsh school reform policies were intended to strengthen the voice and power of local communities, an act of decentralization. The Education Act (No 2) of 1986 increased the responsibilities of Governing Bodies' (similar to School Community Councils) while reducing the power of Local Educational Authorities' (similar to Saskatchewan School Boards) (OECD, 1997). Members of the Governing Body were responsible for such things as the distribution of school finances for staffing and services (Giles, 2006; Thomas, 1993), the creation and implementation of school policies, and the management of programs offered at the school (OECD, 1997). Governing Bodies and head teachers were required to prepare a management plan depicting how they intended to allocate resources and meet national curriculum requirements (Thomas, 1993). The development of such a plan exemplified how the authority of the previously more centralized Local Educational Authorities was shifted to parents and community members. By decentralizing the control of local decision-making and the allocation of resources to Governing Bodies, educators needed to work more closely with parents and community members.

Like the Governing Bodies in England and Wales, Saskatchewan's recent educational reforms also places renewed emphasis on close school-community relationships. As explained by Saskatchewan Ministry of Education (2008), School Community Council members are required to collaborate with the principal and school staff to develop, implement, and evaluate a Learning Improvement Plan, a written strategy definitively depicting how the school and its community intend to improve student learning and achievement. In fact, Endsin and Melvin (n.d.) described a formal and accountable eight-step process which needs to be undertaken by the School Community Council in an effort to assist in the production of the Learning Improvement Plan. These steps include: (a) review the school community profile; (b) establish beliefs and create a vision; (c) reassess needs based on the vision; (d) develop objectives; (e) create an action plan; (f) identify program supports; (g) submit the plan to the Board for approval; and (h) monitor/evaluate the communication (p. 22). 
Upon first consideration, Saskatchewan's Learning Improvement Plan appears to be highly decentralized in nature. However, Saskatchewan Ministry of Education (2008) stated that each Plan needs to align with centralized divisional priorities and practices: "The goals of the LIP [Learning Improvement Plan] should align with the division's CIP [Continuous Improvement Framework] and provincial priorities. The LIP should be developed collaboratively by the Principal, school staff, and School Community Council" (p. 14). Therefore, although the Learning Improvement Plan is intended to reflect the localized needs of a student body, the Plan, itself, must fit within the dimensions of the school division's broader preset requirements. Furthermore, the origins of the school division's goals are heavily influenced by educational mandates predetermined by the provincial government (Saskatchewan Ministry of Education, 2008). Otherwise said, the local goals created within the Learning Improvement Plan need to be in compliance with the centralized educational platform produced by the provincial government. Based on this analysis, School Community Councils' involvement with a Learning Improvement Plan is not a highly decentralized act, but a localized validation of provincial priorities.

As compared to the Governing Bodies of England and Wales, School Community Councils in Saskatchewan have been given far less local authority. As mentioned above, the manipulation of school finances, the authority to implement policies, and the power to legitimize curricular decisions are responsibilities bestowed upon Governing Bodies; conversely, none of these responsibilities are within the power realms of Saskatchewan's School Community Councils. The act of creating local educational goals within a school is not within the sole dimensions of the School Community Council's power either.

\section{Educational Reform in the United States}

Specifically during the 1980s and 1990s within the United States, three distinguishable reform movements came to the fore and are discussed below. They include: the publication of $A$ Nation At Risk, changes to the Chicago public school system, and the creation of charter schools. Notably, A Nation At Risk did not directly induce reform of school governing bodies; however, this document was a catalyst to Chicago public school reforms and the creation of charter schools, which did direct new emphasis on creating more powerful school councils. For that reason, this section starts with an overview of A Nation At Risk. It is worthy to note that a central plank of American educational reform is the No Child Left Behind Act; however, since the No Child Left Behind Act was passed at the turn of the century, the details of that Act will be not be discussed in this article.

\section{A Nation at Risk}

A Nation at Risk, a small but extremely influential federal report, advocated the need for educational reform within the United States. Published in 1983, its warning indicated "...the educational foundations of our society are presently being eroded by a rising tide of mediocrity that threatens our very future as a Nation 
and a people" (The National Commission on Excellence in Education, 1983, p. 5). Under the Regan administration, this report sounded an alarm and "unleashed a firestorm of reform activity" (Koppich \& Guthrie, 1993, p. 51). Within a few months of publication, a fifty-state survey found that 33 states had enacted or were considering legislation to increase teachers' salaries, and seven states had approved legislation to increase the duration of the school day, to increase the number of days in the school year, or to increase both (Koppich \& Guthrie, 1993). By 1986, the impetus to improve schools had generated unprecedented levels of policy-making activity. Many states increased high school graduation requirements, placed more emphasis on mathematics, science, and history, de-emphasized electives, increased standardized testing, and tightened teacher-certification requirements (Koppich \& Guthrie, 1993). Undeniably, from citizens across the country, A Nation at Risk drew attention to the quality and type of education Americans were receiving.

Just as reflected in the aforementioned countries, the momentum supporting the publication of $A$ Nation at Risk was economic and political by nature. In the early 1980s, the United States was importing more than it was exporting (especially from Japan), and America intended to enhance its global influence and power through restructuring urban industries (McCall, Parker, \& MacDonald, 2007; Guthrie \& Koppich, 1993). The United States proposed to increase its educational productivity, enhance its human capital, prepare a productive workforce for the $21^{\text {st }}$ century, and thereby become a fierce competitor of other industrialized, technologically-sharp economies similar to Japan (Guthrie \& Koppich, 1993). The recommendations presented within A Nation at Risk supported the mission to rejuvenate the strength of the nation. Education was the panacea of this vision, as American leaders believed that a well-educated and highly skilled workforce was vital in adopting new technologies and innovative practices.

\section{Chicago Public School System}

A Nation at Risk did impact national educational reform across the United States throughout the 1980s and 1990s; however, each state experienced variegated types of educational reform because state governors and state-school officers were individually responsible for regulating new educational policies within specific states. One region that clearly demonstrated radical educational change, specifically within the school governance domain, was the state of Illinois. By the late 1980s, the push for increased community involvement within schools was vividly displayed in the city of Chicago. According to Rist (1990), parents spearheaded changes in Chicago's public school system by calling to attention their widespread dissatisfaction with the city's schools. Schools were overcrowded and in need of repair; ordering supplies placed no guarantee that orders would be filled; the system was short 2,000 teachers; and student achievement was ranked the lowest in the United States. Parents began to organize city-wide conferences directed at school improvement and vehemently displayed their frustrations with the centralized administration by lobbying the state legislature.

Parent/community synergy resulted in the passing of the Chicago School 
Reform Act of 1989, which initiated sweeping changes in Chicago's Public School system. Each school was mandated to form a Local School Council (similar to a School Community Council) consisting of six parents, two teachers, two community representatives, the principal, and a high school student (where applicable) (Flinspach \& Ryan, 1994). The legislation transferred considerable decision-making power to local schools and community members. Local School Council responsibilities included the hiring and evaluating of administrators, the approval and monitoring of a School Improvement Plan, and the budgeting of the school's funds. Within Chicago there was a rapid departure from a centralized style of educational governance, and parents and community members were instated as the school's main decision-making body.

When comparing Saskatchewan's School Community Councils with Chicago's Local School Councils, similarities include a close resemblance in membership requirements and a parallel responsibility exemplified through the creation of a School Improvement Plan (or Learning Improvement Plan, as it is referred to within Saskatchewan). However, within Chicago, the Local School Council had more influence and authority than School Community Councils do in Saskatchewan. Specifically, the power to hire and fire administrators and the responsibility of the school's budget are not within the power realm of Saskatchewan's School Community Councils.

\section{Charter Schools}

Just as within Chicago schools, charter schools place great emphasis on local governance. In fact, Schroeder (2004) believed the creation of charter schools, a.k.a. public schools of choice, began a revolution in the organization of governance within public education. In 1991, the State of Minnesota legislated the first charter school law within the United States. The idea behind this transformational school was simple: it was a way to grant parents, teachers and community members the opportunity to establish and govern public schools, which were to be outside the control of a local school district. As such, a group of community members were in charge of developing its own pedagogical policies that would respond more effectively to the distinct needs of children (Gallagher, 1995).

Charter schools are authorized by the state for a specific amount of time and granted a charter, which defines academic and other goals of the school's operation. They abide by principles of public education in that they are publicly funded, nondiscriminatory in acceptance, and have no religious affiliation or attachment to curricula (Schroeder, 2004). However, unlike publicly funded schools, few states provide the finances for acquiring the infrastructure required to start these schools (Lake \& Hill, 2005). Because charter schools are monitored by each state, specific policies underlining the creation and sustainability of these schools differ from one state to another (Stillings, 2005). The popularity of these schools grew quickly in the United States, and, by the 2006-2007 school year, there were well over one million students enrolled in 3,940 charter schools across 40 states and Washington, D.C. (The Center for Education Reform, 2007). 
In 1994, charter schools were introduced within the province of Alberta (Ungerleider \& Levin, 2007). Alberta still remains Canada's only province with charter schools, with 13 charter schools currently in operation (Alberta Education, 2008). The curricular focus of each charter school in Alberta differs, ranging from, for example, ESL, students at risk, infusions of the arts, girls as leaders, and science and technology. Although charter schools do not exist, per se, in Saskatchewan, the structure and governance seen in charter school is similar to the structure and governance as found in Saskatchewan's associate schools Specifically, Saskatoon Catholic Schools have five high schools, 34 elementary schools, and two associate schools (First Nations and Métis Relations, 2005). The names of Saskatchewan's two associate schools are: Oskayak High School (formally known as Joe Duquett High School) (Zary, 2007) and Saskatoon French School (SaskTel, 2006/2007, p. 1397).

Although there are various models of charter school governance, the types that prevail within most of these schools include: (a) a School Council; (b) a Board of Directors with delegation of management to the principal; (c) an owner/operator with a School Advisory Committee (Martinelli, 2000). Within all of these governing committees, membership includes parents, educators, and community members (OECD, 1997). Although the responsibilities of School Councils in American charter schools differ according to the school, predominantly School Councils in charter schools hold such duties as developing yearly goals for the school, approving the annual budget, and preparing an annual assessment of the educational program of the school (Freshwater Charter Middle School, 2004). In essence, parents and community members direct public education to suit their needs, thus creating a school that becomes "part of the fabric of public life in their communities" (Lake \& Hill, 2005, p. vii). Lake and Hill (2005) believed that charter schools are an ideal way to bring the community into direct partnership with a school.

Saskatchewan's School Community Councils are also a means by which community members are to become directly involved with the school (Saskatchewan Learning, 2005). That is, School Community Councils, like the governing boards and School Councils of charter schools, are mandated to purposefully weave aspects of the community into their school. However, other than being mandated to increase community involvement and having similar representation requirement for governing body membership, School Community Councils and charter school councils differ greatly. The School Community Council is not as powerful because, as indicated previously, School Community Councils have no formal curricular persuasion and no financial/budgetary responsibilities.

\section{SOCIETAL ISSUES ENDORSING SCHOOL REFORM AND THEIR APPLICATION TO SASKATCHEWAN}

An international backdrop indicative of some of the major educational reform movements during the 1980s and 1990s has been depicted above. This section presents an analysis of how educational reform is influenced by political and 
economic concerns particularly within Saskatchewan. Societal issues pertaining to decentralization, privatization, and accountability are explained and juxtaposed by a discussion within a Saskatchewan context.

\section{Political Motivation and Economic Hardships}

Throughout England, Wales and the United States, educational reform was predominantly driven by political incentives. That is, educational reforms did not originate from educators; educational reforms were mandated by external political influences. Koppich and Guthrie's (1993) term, high politics, can be appropriately applied to describe the general push behind education reforms. During the period under review, education had become an increasingly malleable instrument utilized by political systems throughout England, Wales, and the United States.

Within Saskatchewan, there are diverse examples of how education and politics merge. For instance, in Saskatchewan the government supplies circa 50 percent of public education expenses (Lee, 2008), and currently Saskatchewan's educational taxes are the highest in the country (Lee, 2008; Norton, 2008). For this reason, the Saskatchewan Real Estate Association (SREA) lobbied the provincial government demanding lower educational taxes on property (French, 2005). Since educational taxes compose the largest portion of property tax, the issue of property/ education tax is especially significant in rural areas because of the rates of taxation on farmland. Land being the core to a successful business, farmers, for the most part, own more property than the general population. Farmers are responsible for paying property tax on each piece of land they own, and, as such, high property taxes continue to be a concern for farmers. As a result, in 2006, a number of farmers refused to pay, what they believed to be, exorbitant amounts of educational taxes. In retribution, Saskatchewan school divisions prepared to sue 122 rural municipalities for withholding money (the educational tax portion of property taxes) from school divisions (Saskatchewan News Network, Regina, 2006). Within these examples, the politics of provincial property tax policies and educational issues clash. A critique of this scenario reveals components of irony. Although a vast amount of funding for Saskatchewan's education is taken directly from the pockets of community members, when it comes to participating in decisions involving how this money will be allocated, local School Community Councils have been given no authority.

Another relevant aspect within the topic of taxation and funding are details pertaining to age demographics of taxpayers juxtaposed by the educational needs of their children. Within Saskatchewan and Canada, the overall age of citizens is rising: one out of every seven Canadian citizens is over the age of 65 (Greenaway, 2007), and the average age of a Saskatchewan farmer is 52 (Statistics Canada, 2007). An aging population dictates that a larger portion of citizen no longer have school-age children. A concern now voiced by some older citizens questions why they are compelled to pay exceedingly high educational taxes when they do not directly benefit from their tax contributions. Assigned to this premise is the following idea: perhaps, School Community Councils are a/an (placebo) effort by the provincial government to appease the said concerns of Saskatchewan's aging 
citizenry, an increasingly powerful political influence. If more community members are directly involved within their local school, invariably, they will experience greater connections with the students and the school. Even small connections with public education may placate some concerns of older tax-paying citizens.

Another summative point which can be made about international educational reform movements deals with the economy. In the 1980s, many countries were nearing bankruptcy, and economic hardships manipulated the nature of educational restructuring. In an effort to enhance competitiveness within international markets, each country attempted to increase its human capital potential through initiating new educational policies. Interestingly, an overview of Saskatchewan's economic state draws stark contrasts to international portraits painted during the 1980s and 1990s. Although poor economies stimulated international reform to educational governance, a solid economy is currently invigorating the financial foundation of Saskatchewan. Saskatchewan's oil and gas industry are at an all-time high, and mining, Saskatchewan's third largest industry, is experiencing unprecedented prosperity (Government of Saskatchewan, 2006). The provincial debt is at a 20 year low (Government of Saskatchewan, 2008). The province's unemployment rate for October 2008 was down to 4.1 percent, highlighting this province's robust economic growth (Statistics Canada, 2008). Saskatchewan's red-hot economy is driving a flurry of construction work both commercially and residentially, all of which are contributing to the severe shortage of skilled workers in the province (Canadian Federation of Independent Business, 2008). So, if economic issues are not propelling educational reform within Saskatchewan, what is the impetus behind the educational changes Saskatchewan is currently undergoing?

In response to the above question, one reason behind Saskatchewan's reforms is based on property tax inequalities that were caused by the multitude of small schools divisions that previously made up Saskatchewan's educational system. Prior to amalgamations, Saskatchewan's 82 school divisions, on average, encompassed about 2,100 students each. Within Canada in 2004, the average student enrollment per division was 12,500 (Saskatchewan Learning, 2004). Since Saskatchewan amalgamated, the number of students in each division falls closer in line with the preceding examples, as each of Saskatchewan's 28 new school divisions has about 5,000 students (Saskatchewan Learning, 2005). A common argument made for restructuring school divisions is that by merging and reducing the number of school divisions, tax bases are equalized among larger geographical areas.

Piggy-backing upon educational reforms of school amalgamations was the creation and implementation of School Community Councils. Dolan (1994) believed if education is to successfully implement major reforms, the entire system needs to be seen as an interconnected entity, and, accordingly, reforms need to be bestowed upon schools, districts, and governance boards and management. Within the realms of this premise, it is understandable that Saskatchewan Learning decided to conglomerate changes to school districts and school governance systems simultaneously. Thus, indirectly, the amalgamations and tax base equities were stimuli behind the creation of School Community Councils. 


\section{Proponents of Decentralization}

A common thread running throughout the international examples is that decentralization ideologies pervaded educational reform. In the aforementioned cases, power and authority within education were devolved to parents/community members by raising the level of responsibilities of local school governing bodies such as school councils. Thus, instead of federal, provincial, state, and/or school division jurisdictions sustaining sole responsibility for the education of society, local governing bodies became more accountable for the educational administration, enhancement, and sustainability of youth.

Decentralization has the potential to enable community participation and inclusiveness, hallmarks of democracy. Democracy emphasizes cooperation among people, caring for the common good, and opportunity for all to voice their opinions (Beane \& Apple, 1995). In the early twentieth century, Dewey (1916) believed that within a democracy, public education should provide the school community with opportunities to socially interact and directly participate within local decisionmaking processes and authorities. One of the overarching aims of school councils is to share a portion of the responsibility of students' learning and wellbeing with the school community. In this age of democratization, the term sharing infers giving administrators, teachers, parents, and students a distinctive voice in the education process.

In most western countries, democratic ideologies have been extended to the governing roles that local parents and community members uphold within the school. Brown (1990) suggested the label "parentocracy" (p. 65) when referring to educational policy that promotes the needs and desires of the parents in schools. Corter and Pelletier (2005) claimed, "Parent involvement in governance...may be seen as inherent rights of individuals that do not need to be justified by increases in student achievement" (p. 301). These abundant citations reiterate how trademarks of decentralization and components of democracy closely align.

Democratic ideologies and decentralized tendencies can only successfully permeate a community, if communication within the community is lucid. Endsin and Melvin (n.d.) believed that School Community Councils will, in fact, help to ensure that communication within the community remains strong. These authors stated, "School Community Councils engage in processes to ensure all voices in the school community are heard and all perspectives are taken into account" (p. 8). However, an element of uncertainty may accompany this statement. To begin with, if School Community Councils are to inclusively promote involvement, the entire community needs to be aware of the existence of the council, the purpose of the council, and the potential benefits of the council to the school and community. In an Ontario study, which surveyed community members, most non-school council members could not even recall the names of school council members (Corter, Harris, \& Pelletier, 1998). It is difficult for a school council to actively promote an inclusive community voice when members within the school community are not even aware of contacts for school council members. Hence, in an effort to entice community involvement, it is imperative that the existence of a School Community Council be known within the school community, and that the reputation of the 
Council be warm and welcoming so that community members are not intimidated in any way by the School Community Council.

\section{Opponents of Decentralization}

Townsend (1996) so blatantly described what he believed to be negative underlying reasons why governments decentralize educational governance: "Restructuring is a deliberate attempt by governments to offload the state's responsibility for education of the population onto individual communities and then try to blame those communities if they don't satisfy government requirements" (p. 3). Lawton's (1996) comments about decentralization tendencies parallel Townsend's ideas. Lawton believed that through increased decentralization, senior levels of government download their fiscal problems to local jurisdictions, thereby producing scapegoats (p. 179). Smyth (1993) concurred that governments promote decentralized school governance when they need to enforce educational cut-backs. During financially insecure times, the notion of self governance is used as a weapon to achieve alleged efficiencies of education while decreasing funding. Exemplified within the presented international countries, financial challenges did accompany decentralized school governance reforms; however, as stated previously, within Saskatchewan, the driving force behind current educational reforms is not due to a dormant economy.

There are additional concerns associated with a highly decentralized model of school governance. Chapman (as cited in Townsend, 1996) explained that if school governance is highly decentralized, richer communities will naturally be able to provide extra funding and resources for their schools, and consequently a higher quality of education for their students. Furthermore, a highly decentralized governance often relies on volunteers. The voluntary nature of school governing bodies is a point of contention, because placing large responsibilities upon a volunteer organization tends to produce fewer guaranteed results as compared to when membership within an organization is a paid position. Veeman, Ward, and Walker (2006) explained that the capacity of voluntary sectors is eroded when increased accountability and self-sufficiency pressures are bestowed upon them. Stelmach and Preston (in press) also voiced concerned about how voluntary representation may be an issue for School Community Councils. These authors recognized, for example, that without training, voluntary members on the school council may be ill-equipped to deal with highly specialized educational decisions such as creating and implementing Learning Improvement Plan.

\section{Forms of Accountability}

Behn (2004) believed, "Everyone wants accountability in education" (p. 19). As mentioned previously, the intention to increase school governance accountability was apparent within international settings during the 1980s and 1990s. Within Chicago schools, Local School Councils were required to write a plan which outlined how they were going to improve student academics (Flinspach \& Ryan, 1994). In England and Wales, standardized test scores made school councils more accountable for student performance (Fujita, 1999). Many writers believe that focusing on accountability and standardized tests as a central means to define 
school quality usurps the rights of local communities to define what they see as a quality education (Karp, 2004; Meier, 2004; Wood, 2004). Meier (2004) stated, "Districts are further encouraged to limit any local alternative by having schools limit their curriculum time to what will prepare children for tests" (p. 71). Otherwise said, formally ascribing to a specific national vision leaves little room for the selfregulation of local needs and desires; centralized accountability efforts may, in fact, undermine local community development and pride. In addition, although academic levels of a student may or may not be measured via standardized tests, standardized tests do little to represent and promote the social development of a student, and, in order for a community to thrive, its members must be skilled and confident within social domains.

Within some Canadian provinces (i.e. Alberta), student achievement, assessed by standardized tests, is publicly reported; however Saskatchewan does not presently promote such accountability tactics. Fred Wendel, Saskatchewan's Auditor General, noted that the Saskatchewan educational sector fails in its formal accountability effort ("School Boards Need Better Accountability," 2005). For example, Saskatchewan produces limited public information regarding student achievement, has limited protocol assigned for assessment of practicing teachers, and has no clear provincially-legislated tacit to measure the effectiveness of the province's curriculum ("School Boards Need Better Accountability," 2005). However, within the United States and throughout Canada, accountability has been an extremely popular topic throughout the past decade. As mentioned above, Saskatchewan has followed international and national trends as exemplified in its current move to legislate School Community Councils. If Saskatchewan continues to follow by example, in the near future, the province may submit to neighboring pressures and increase its formal accountability policies.

\section{Conclusion}

The review of international educational reform, anchored within the timeframe of the 1980s and 1990s, identified motives and rationales pervading changes in school governance. Namely, economic and political determinants, a desire to decentralize school governance, compliance to trend-setting policies, privatization tendencies, and accountability tactics have been the common fuses used to ignite a global grassfire of educational reform specifically within the realm of school governance. Within this international epoch of educational reforms, most forms of school councils were given the authority to make decisions pertaining to school-related issues and financial matters. Approximately 25 years on, Saskatchewan is experiencing similar changes to its school governance system as those experienced by various other countries; however, the economic and politicalwill of the province and the responsibilities given to School Community Councils contrast greatly with the above international models. Saskatchewan, with a booming economy and a socialist government, implemented school councils, which have little to no real authority over local educational decisions or financial concerns. In addition, as compared to the international trend, the impetus for establishing School Community Councils originated from other sources - possibly from the overarching structural changes that were already in motion (i.e. amalgamations and taxation 
issues) or from a "Canadian Simon-Says-Reflex," in that all other provinces/ territories had implemented school councils within the past 15 years (see Preston, 2008).

In sum, when comparing Saskatchewan's School Community Councils to aforementioned international forms of school councils, one major difference surfaces: School Community Councils are advisory bodies with limited power; international school councils are quite powerful decision-making bodies with far-reaching responsibilities. Although decision-making powers and financial authorities are imbalanced when comparing international forms of school councils and School Community Councils, ironically, both forms of school councils have aligned purposes: to positively influence student learning and well-being and to increase community involvement. It is important to note that School Community Councils are in their infancy stages of development. What is to be yet determined is their ability to meld schools and community into a more fecund, cohesive relationship that positively affecting the lives of students.

\section{References:}

Alberta Education. (2008, November 6). Alberta Education: Public, Separate, Francophone, and Charter Authorities. Retrieved November 10, 2008, from http://education. alberta.ca/ei/reports/pdf_files/eis1005p/eis1005pbody.pdf

Beane, J. A., \& Apple, M. W. (1995). The case for democratic schools. In M. W. Apple \& J. A.

Beane (Eds.), Democratic schools (pp. 1-25). Alexandria, VA: Association for Supervision and Curriculum Development.

Beare, H., \& Boyd, W. L. (Eds.). (1993). Restructuring schools: An international perspective on the movement to transform the control and performance of schools. Washington, DC: The Falmer Press.

Behn, R. D. (2004). Rethinking accountability in education: How should who hold whom accountable for what? In L. Jones, K. Schedler \& R. Mussari (Eds.), Strategies for public management reform (Research in public policy analysis and management, Volume 13) (pp. 19-53). St. Louis, MO: Elsevier Ltd.

Bolton, E. (1993). Imaginary gardens with real toads. In C. Chitty \& B. Simons (Eds.), Education answers back (pp. 3-17). London, UK: Lawrence and Wishart.

Brown, P. (1990). The 'third wave': Education and the ideology of parentocracy. British Journal of Sociology of Education, 11(1), 65-86.

Canadian Federation of Independent Business. (2008, March 7). Help Wanted Concern over shortage of labour continues to grow: Saskatchewan's long-term vacancy rates highest in country. Retrieved November 5, 2008, from http://www.cfib.ca/en/ media/releases08/sk030708.asp

The Center for Education Reform. (2007). 2007 Annual survey of America's charter schools. Washington, DC: Author. Retrieved November 10, 2008, from http://www. 
edreform.com/_upload/cer_charter_survey_2007.pdf

Corter, C., Harris, P., \& Pelletier, J. (1998). Parent participation in elementary schools: The role of school councils in development and diversity. Toronto, ON: Report on the Ontario Ministry of Education and Training on Research.

Corter, C., \& Pelletier, J. (2005). Parents and community involvement in schools: Policy panacea or pandemic? In N. Bascia, A. Cumming, A. Datnow, \& K. Leithwood (Eds.), International handbook of educational policy (pp. 295-327). Norwell, MA: Springer.

Dewey, J. (1916). Democracy and education. New York: Macmillan.

Dolan, W. P. (1994). Restructuring our school: A primer on systemic change. Kansas City, MO: Systems \& Organization.

Endsin, R., \& Melvin, C. (n.d.). School Community Councils: A handbook for School Community Councils and principals. Saskatchewan School Boards Association.

First Nations and Métis Relations. (2005, February 25). Job Opportunities for First Nations and Métis People. Regina, SK: Government of Saskatchewan. Retrieved January 2, 2008, from http://www.fnmr.gov.sk.ca/news/2005 02 25SCS.htm

Flinspach, S. L., \& Ryan, S. P. (1994). Diversity of outcomes: Local schools under school reform. Education and Urban Society, 26(3), 292-305.

French, J. (2005, November 15). Real estate association joins lobby for lower educational taxes. The StarPhoenix, A9.

Freshwater Charter Middle School. (2004). Freshwater Charter Middle School mission statement. Eureka, CA: Author.

Fujita, H. (1999, January 18-21). Choice, quality and democracy in education: A comparison of current educational reforms in the United States, the United Kingdom and Japan. A paper presented at The International Symposium of the Public and the Private in the United States, Retrieved June 19, 2008, from http://www.childresearch.net/ RESOURCE/RESEARCH/2000/FUJITA/index.html

Gallagher, P. (1995). Changing course: An agenda for real reform of Canadian education. Toronto, ON: The Ontario Institute for Studies in Education.

Giles, C. (2006). School development planning in England and Wales (1988-1992): An insight into the impact of policy recontextualization on the initiation and early implementation of decentralized reform. Journal of Educational Administration and History 38(3), 219-236.

Government of Saskatchewan. (2006, March 6). Mineral exploration boom continues. Retrieved July 31, 2008, from http://www.gov.sk.ca/news?newsId=160ff5ced7eb-4b7b-a696-e9ed24499ed9

Government of Saskatchewan. (2008). Fact sheet: Premier's fall 2008 announcement. Retrieved November 5, 2008, from http://www.gov.sk.ca/adx/aspx/adxGetMedia. aspx?mediaId $=600 \& \mathrm{PN}=$ Shared

Greenaway, N. (2007, July 18). Population ages in Canada. The StarPhoenix, C6.

Karp, S. (2004). NCLB's selective vision of equality: Some gaps count more than others. In D. Meier \& G. Wood (Eds.), Many children left behind: How the No Child Left Behind Act is damaging our children and our schools (pp. 53-65). Boston: Beacon Press.

Koppich, J. E., \& Guthrie, J. W. (1993). Examining contemporary education-reform efforts in the United States. In H. Beare \& W. L. Boyd (Eds.), Restructuring schools: An international perspective on the movement to transform the control and performance of schools (pp. 51-68). Washington, DC: The Falmer Press.

Lake, R. J., \& Hill P. T. (2005). Hopes, fears, \& reality: A balanced look at American charter 
schools in 2005. Seattle, WA: University of Washington.

Lawton, S. B. (1996). Financing Canadian education. Toronto, ON: Canadian Education Association.

Lee. H. (2008). Solving the problem: Fixing Saskatchewan's antiquated K-12 funding system. Ottawa, ON: Canadian Taxpayers Federation.

Martinelli, F. (2000, November). Creating an effective charter school governing board guidebook. St. Paul, MN: Charter Friends National Network. Retrieved July 31, 2007, from http://www.uscharterschools.org/governance/

McCall, P. L., Parker, K. F., \& MacDonald, J. M. (2007). The dynamic relationship between homicide rates and social, economic and political factors from 1970 to 2000. Social Science Research, 37(3), 721-735.

Meier, D. (2004). NCLB and democracy. In D. Meier \& G. Wood (Eds.), Many children left behind: How the No Child Left Behind Act is damaging our children and our schools (pp. 66-78). Boston: Beacon Press.

The National Commission on Excellence in Education. (1983). A Nation at Risk: The Imperative for educational reform. Washington, DC: U.S. Government Printing Office.

Norton, M. (2008, October 6). Property taxes take some figuring. Leader Post, B10.

OECD. (1997). Parents as partners in schooling. Paris: Organisation for Economic Cooperation and Development, Centre for Educational Research and Innovation.

Rist, M. C. (1990). Chicago decentralizes. The American School Board Journal, 177(9), 21-24, 36 .

Rudalevige, A. (2003). No Child Left Behind: Forging a congressional compromise. In P. E. Peterson \& M. R. West (Eds.), No Child Left Behind? The politics and practice of school accountability (pp. 23-54). Washington, DC: The Brookings Institution.

Preston, J. P. (2008). School councils: A passing fad or a solid future? Policy and Practice in Education, 14(1/2), 65-84.

Saskatchewan Learning. (2004). Education Equity Initiative. Retrieved August 23, 2007, from http://www.sasked.gov.sk.ca/branches/comm/minister/speeches/faq.shtml

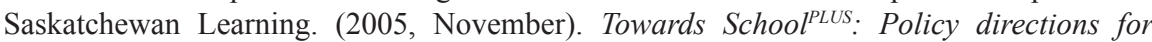
School Community Councils: Provincial response to the Local Accountability and Partnership Panel final report. Retrieved November 5, 2008, from http://www. sasked.gov.sk.ca/branches/comm/minister/speeches/PolicyDirections_Nov05.pdf

Saskatchewan Ministry of Education. (2008). Pre-K-12 Continuous Improvement Framework: A guide for school division strategic planning, Version III. Retrieved November 5, 2008, from http://www.education.gov.sk.ca/adx/aspx/adxGetMedia. aspx?DocID=201,135,107,81,1,Documents\&MediaID=4483\&Filename=Continu ous+Improvement+Framework+Ver+3+Aug-08.pdf

Saskatchewan News Network, Regina. (2006, January 28). School divisions to sue for withheld taxes. The StarPhoenix, A6.

SaskTel. (2006/2007). SaskTel phonebook: Saskatoon city. Saskatoon, SK: Direct West.

School boards need better accountability. (2005, June 13). The StarPhoenix, A8.

Schroeder, J. (2004). Ripples of innovation: Charter schooling in Minnesota, the nation's first charter school state. Washington, DC: Progressive Policy Institute.

Smyth, J. (1993, July 2). Schools of the future and the politics of blame. A paper presented at a public lecture sponsored by the Public Sector Management Institute, Melbourne, Monash University, Australia.

Statistics Canada. (2007). Snapshot of Canadian Agriculture. Government of Canada. Retrieved November 2, 2008, from http://www.statcan.ca/english/agcensus2006/ 
articles/snapshot.htm

Statistics Canada. (2008, November 7). Labour force survey. The Daily. Retrieved November 10, 2008, from http://www.statcan.ca/Daily/English/081107/d081107a.htm

Stelmach, B. L., \& Preston, J. P. (in press). Cake or curriculum? Principal and parent views on transforming the parental role in Saskatchewan schools. International Studies in Educational Administration, 36(3).

Stillings, C. (2005). Charter schools and No Child Left Behind: Sacrificing autonomy for accountability. The Journal of Education, 186(2), 51-70.

Thomas, H. (1993). Read, A.I.M., reform: Building a model of education reform and 'high politics'. In H. Beare \& W. L. Boyd (Eds.), Restructuring schools: An international perspective on the movement to transform the control and performance of schools (pp. 30-50). Washington, DC: The Falmer Press.

Townsend, T. (1996, December). Decentralizing education and improving student outcomes: Implications of the international research for developing countries. A paper presented at The Second Unesco-aceid International Conference Re-engineering Education for Change: Educational Invocation for Development. Bangkok, Thailand.

Ungerleider, C., \& Levin, B. (2007). Accountability, funding and school improvement Canada. In T. Townsend (Ed.), International Handbook of School Effectiveness and Improvement (pp. 411-424). Netherlands: Springer.

Veeman, N., Ward, A., \& Walker, K. (2006). Valuing literacy: Rhetoric or reality? Calgary, AB: Detselig Enterprises Ltd.

Wood, G. (2004). Introduction. In D. Meier \& G. Wood (Eds.), Many children left behind: How the No Child Left Behind Act is damaging our children and our schools (pp. vii-xv). Boston: Beacon Press.

Zary, D. (2007, February 15). High school hockey coming to Saskatoon. The StarPhoenix, B2.

Jane Preston is in Educational Administration in the College of Education at the University of Saskatchewan and can be reached at jpp197@mail.usask.ca. 